\title{
Terrestrial bromeliads as seed accumulation microsites in a xerophytic forest of Southern Chaco, Argentina
}

\author{
Las bromeliáceas terrestres como micrositios de acumulación de semillas en un bosque xerofítico \\ del Chaco Austral, Argentina
}

\author{
Ignacio Martín Barberis ${ }^{\text {a,b }}$ *, Silvia Irene Boccanelli a , Claudia Alzugaray a \\ *Corresponding author: ${ }^{a}$ Universidad Nacional de Rosario, Facultad de Ciencias Agrarias, CC 14 (S2125ZAA) Zavalla, \\ Argentina, tel.: +54 341 4970080, fax +54 341 4970080, ignaciobarberis@yahoo.com \\ ${ }^{\mathrm{b}}$ Consejo Nacional de Investigaciones Científicas y Técnicas (CONICET), Argentina.
}

\begin{abstract}
SUMMARY
The understory of the Schinopsis balansae forests of Southern Chaco is frequently covered by dense populations of two bromeliad species (Aechmea distichantha and Bromelia serra). These bromeliads usually act as traps capturing propagules and litter falling from the canopy. Some populations of these bromeliad species have been removed to ease cattle management, without considering their possible effects on forest regeneration. Therefore, the objective of this work was to evaluate the importance of both bromeliads as microsites for seed accumulation of woody and herbaceous species. Ten plots with bromeliads were selected, where one soil sample and one plant of each species were taken. From the material collected among bromeliad leaves, the seeds and propagules were separated. Likewise, soil samples were washed and the seeds were separated from the litter collected. Seeds were determined to morphospecies and counted. There were 352 seeds ( 230 on bromeliads and 122 in the soil) from 48 species (10 woody and 38 herbaceous species). Seed abundance of woody species was higher on bromeliad plants (70 seeds) than on the soil (six seeds). In contrast, a higher richness of herbaceous species was recorded on the soil. Therefore, both bromeliads seem to be important microsites for seed accumulation of woody species. However, it is not known whether bromeliads are a safe site for seedling establishment.
\end{abstract}

Key words: bromeliads, Chaco, seeds, understory.

\section{RESUMEN}

El sotobosque de los quebrachales de Schinopsis balansae del Chaco Oriental está frecuentemente cubierto por densas poblaciones de dos bromeliáceas terrestres (Aechmea distichantha y Bromelia serra). Estas bromeliáceas actúan como trampas que capturan propágulos y hojarasca que cae desde la copa de los árboles. Estas poblaciones son a veces removidas para facilitar el manejo del ganado, sin considerar los posibles efectos sobre la regeneración del bosque. El objetivo de este trabajo fue evaluar la importancia de ambas bromeliáceas como micrositios para la acumulación de semillas de especies leñosas y herbáceas. En diez áreas con bromeliáceas, se tomó una muestra de suelo y una planta de cada especie. Se procesó el material colectado entre las hojas de las bromeliáceas, separando las semillas. Además, se lavaron las muestras de suelo, separando las semillas de la hojarasca colectada. Las semillas fueron determinadas al nivel de morfoespecie y contadas. Se registraron 352 semillas (230 sobre bromeliáceas y 122 en el suelo) de 48 especies (10 leñosas y 38 herbáceas). Las semillas de leñosas fueron más abundantes en las plantas de bromeliáceas (70 semillas) que en el suelo (seis semillas). Por el contrario, se registró una mayor riqueza de especies herbáceas en el suelo. Por consiguiente, ambas bromeliáceas parecen ser importantes micrositios para la acumulación de semillas de leñosas. Sin embargo, no se sabe si las bromeliáceas constituyen un micrositio propicio para el establecimiento de plántulas.

Palabras clave: bromeliáceas, Chaco, semillas, sotobosque.

\section{INTRODUCTION}

The understory of numerous forests around the world is known to reduce tree species regeneration by a combined action of direct and indirect mechanisms of interference (Royo and Carson 2006, Caccia et al. 2009). Direct mechanisms are produced by resource competition (e.g. light, water, nutrient), allelopathy, physical impediments to germination due to litter accumulation, or mechanical damage. Indirect mechanisms, on the other hand, are produced by providing refuge to seed or seedling predators (indirect competition). However, plant species in a community may interact negatively as well as positively. The net result of these interactions could vary from positive to negative, because positive effects (e.g. facilitation) frequently act simultaneously with negative effects (e.g. competition or interference; Brooker et al. 2008, Caccia et al. 2009). For instance, some understory species such as palms (Palmaceae), ferns (Pteridophyta), cycads (Cycadaceae) and bromeliads (Bromeliaceae), are known to capture and retain litter and propagules falling from the canopy due to the arrangement of their stems and leaves 
(Álvarez-Sánchez and Guevara 1999, George and Bazzaz 1999, Brancalion et al. 2009). The propagules retained inside the canopy of these understory plants may be protected against seed predators moving at the ground level (Caccia et al. 2006, 2009) and probably against being washed away by water. However, although these microsites are a good place for seedling establishment of some woody species (Fialho 1990, Fialho and Furtado 1993, Sampaio et al. 2005), they are not for others (Brancalion et al. 2009). Therefore, the understory acts as a filter that allows growth of only some woody species (George and Bazzaz 1999, Caccia et al. 2009) and produces significant effects on the dynamics of forest regeneration (Brokaw 1983, Fialho 1990, Fialho and Furtado 1993, Caccia et al. 2006, Brancalion et al. 2009).

Terrestrial bromeliads are a common feature of the understory of several tropical and subtropical forests (Brokaw 1983, Wenzel and Hampel 1998, Sampaio et al. 2005). Most of these terrestrial bromeliads are perennial plants with clonal reproduction, long life-spans and slow growth rate (Benzing 2000). However, these species may differ in several morphological, physiological and ecological characteristics (Benzing 2000). The understory of these forests is frequently covered by two different types of bromeliads. One group is composed by terrestrial or facultative epiphytic species, with mechanical or conditional absorptive roots and a well-developed phytotelma, in which rainwater and litter are accumulated (type III sensu Benzing 2000). The other group, in contrast, is composed by terrestrial bromeliads with absorptive soil roots and weakly developed phytotelma (type II sensu Benzing 2000).

In the xerophytic forests of Southern Chaco, bromeliads from both ecophysiological groups coexist (Barberis et al. 2002). For instance, the understory of the Schinopsis balansae Engl. forests is frequently codominated by two prickly bromeliads Aechmea distichantha Lem., type III and Bromelia serra Griseb., type II (Barberis and Lewis 2005). These prickly bromeliads formed dense colonies that sometimes cover almost half of the understory area (Barberis and Lewis 2005). Several authors argued that these bromeliads may affect woody species regeneration by capturing seeds inside their tanks and by competing for light, water and nutrients with seedlings and saplings and may also affect cattle management by restricting animal movement (Martínez Crovetto 1980, Wenzel and Hampel 1998). Moreover, as tank bromeliads (i.e. A. distichantha) hold water inside their tanks (Cavallero et al. 2009), where a diverse arthropofauna develops (Montero et al. 2010), they are supposed to affect water and nutrient dynamics. Therefore, these authors recommend eliminating these bromeliad populations (Martínez Crovetto 1980, Wenzel and Hampel 1998) to facilitate woody regeneration and cattle management without taking into account the importance of these bromeliad species for the biodiversity and functioning of the ecosystem.
In this work we explored the importance of the bromeliads $A$. distichantha and $B$. serra as microsites for seed accumulation of woody and herbaceous species in the understory of a S. balansae forest from Southern Chaco, Argentina. If bromeliads, due to their plant architecture, act as a microsite where seeds accumulate in this type of forest (Martínez Crovetto 1980), then we predict that (1) there will be higher seed abundance and species richness inside bromeliads than on the soil. If seed accumulation differs between bromeliads with different architecture (Benzing 2000), then we predict that there will be higher seed abundance and species richness inside $A$. distichantha (type III bromeliad) than on B. serra (type II bromeliad). Finally, given the structure and height of both bromeliad species with regard to the surrounding vegetation, we predict that seed accumulation on bromeliads will be higher for woody than for herbaceous species.

\section{METHODS}

Study site and study species. The study was carried out in a 400-ha forest of $S$. balansae ('quebrachal'; Lewis et al. 1997) located at Las Gamas, Santa Fe, Argentina (29 $28^{\prime} \mathrm{S}-60^{\circ} 28^{\prime} \mathrm{W}, 58 \mathrm{~m}$ a.s.1.). The climate is humid temperate to warm (mean annual precipitation $1,000 \mathrm{~mm}$, mean annual temperature $20^{\circ} \mathrm{C}$ ), with frequent frosts in winter (Espino et al. 1983). Rainfall is concentrated in summertime (December-March), while a dry season occurs in winter (June-August). Soils have low hydraulic conductivity and high sodium content (Espino et al. 1983). In this xerophytic forest most woody species are deciduous (Lewis et al. 1997). The structure and floristic composition change markedly in tens of meters in relation to microtopography and soil moisture. Tree and shrub densities are higher in areas with convex topography (Barberis et al. 2002), where there are also dense populations of the two studied bromeliads: B. serra and A. distichantha (Barberis and Lewis 2005).

Bromelia serra thrives on deciduous, semideciduous and evergreen forests in Paraguay and northern Argentina. It is a terrestrial bromeliad (type II sensu Benzing 2000) with long, narrow leaves with armed borders. Plants are pollinated by birds and seeds are dispersed by mammals. It also reproduces vegetatively by stolons (Smith and Downs 1979). Aechmea distichantha occurs as a terrestrial or epiphytic plant in deciduous, semideciduous and evergreen forests from sea level to $2400 \mathrm{~m}$ of altitude in southern Brazil, Bolivia, Paraguay, Uruguay, and northern Argentina (Smith and Downs 1979). It is a tank-forming bromeliad (type III sensu Benzing 2000), with leaves arranged in a very dense rossette that accumulates water in the tank (Cavallero et al. 2009), where many arthropod species grow (Montero et al. 2010). Blades are pungent with armed borders and the sheaths have entire borders (Smith and Downs 1979). Plants reproduce both sexually and asexually, and are pollinated by birds. 
Sampling. In December 2004, before the start of the seed rain of most woody species, ten plots with dense bromeliad understory were selected within a 70 ha paddock, taking into account that they were separated at least by $20 \mathrm{~m}$. In each of them, three microsites where seeds may acummulate (i.e. the canopy of A. distichantha and $B$. serra plants and the soil close to them) were distinguished. In each area, an intermediate to large individual of each bromeliad species was chosen, and a soil sample about $15 \mathrm{~cm}$ in depth and $15 \mathrm{~cm}$ in diameter between both plants was taken. For each plant, the height from the soil to the top leaf was measured, and the crown diameter was calculated based on two perpendicular measurements. The plants were carefully dislodged, pruned, placed into plastic bags and transported to the lab, where they were carefully dismantled. The litter kept on bromeliad leaves and inside their tanks was collected and searched for seeds. The soil samples were washed, sieved through a $0.5 \mathrm{~mm}$ sieve, and then carefully searched for seeds. The seeds were air dried, identified and counted under a dissecting microscope with 10x magnification. We only counted those seeds that remained intact after being gently pressed (Tuesca et al. 2004). For each microsite, seed abundance and species richness were calculated and beta diversity was estimated as total richness divided by the average richness per sample. Species were classified either as woody or herbaceous. Nomenclature follows Pensiero et al. (2006).

Data analyses. Differences in plant diameter and height between both bromeliad species were analyzed with a paired t-test. Differences in seed abundance and species richness among microsites were evaluated with an analysis of variance with randomization testing (MULTIV program; Pillar 2004), because these data were not normally distributed. The Euclidean distance was used as a measure of dissimilarity and the sum of squares $\left(\mathrm{Q}_{\mathrm{b}}\right)$ as a test criterion (Pillar 2004). The plots were included as blocks. All statistical analyses were separately run for woody and herbaceous species. Then, further tests were carried out to analyze whether there were differences among microsites in the relative seed abundance and the proportion of woody species (i.e. woody species/all species).

The total species richness of the three microsites was compared by rarefaction curves. Curves were built by calculating mean species richness values from random samples of increasing abundance, with 1,000 iterations for each abundance level, using the EcoSim program (Gotelli and Entsminger 2002).

\section{RESULTS}

Bromeliads differed in their plant architecture. Aechmea distichantha plants were taller than $B$. serra ones $(0.91 \mathrm{~m} \pm 0.02 \mathrm{~m}$ vs. $0.58 \mathrm{~m} \pm 0.04 \mathrm{~m}$; mean \pm s.e.m.; $\mathrm{t}=7.09 ; P<0.001)$. However, $A$. distichantha plants had shorter diameters than $B$. serra ones $(1.16 \mathrm{~m} \pm 0.05 \mathrm{~m}$ vs.
$1.65 \mathrm{~m} \pm 0.07 \mathrm{~m} ; \mathrm{t}=-5.74 ; P<0.001)$.

There were 352 seeds from 48 species (10 woody and 38 herbaceous species) recorded from all microsites (table 1). Only two woody species (Schinopsis balansae and Acanthosyris falcata Griseb.) and two herbaceous species (Panicum sp. and Sisyrinchium minutiflorum Klatt) were recorded in all three microsites, whereas most species were found in only one microsite (seven out of 10 woody and 32 out of 38 herbaceous species) (table 1). The most abundant and frequent woody species on bromeliads was $S$. balansae, whereas it was uncommon on the soil (table 1).

Seeds of woody species were found on almost all bromeliad samples (90\% for A. distichantha and $80 \%$ for $B$. serra), but only in few soil samples (20\%). Thus, seed samples of woody species had lower beta diversity on A. distichantha and B. serra (4.00 and 4.55, respectively) than on the soil (10.00). In contrast, herbaceous species were found in many bromeliad plants (50\% for A. distichantha and $60 \%$ for B. serra), and in all soil samples. Thus, seed samples of herbaceous species showed similar beta diversity among microsites (A. distichantha: 5.56, B. serra: 6.84 and soil: 5.49).

There were significant differences in the seed abundance of woody species among microsites; on A. distichantha plants there were more seeds than on the soil, whereas the seed abundance on $B$. serra plants was not different from the other two microsites (figure 1A). In contrast, there were no differences in the seed abundance of herbaceous species among microsites (figure 1B). Therefore, the relative abundance of seeds from woody species was higher on A. distichantha and B. serra plants than in the soil samples (figure 1C).

There were no significant differences in the species richness of woody species among microsites (figure 1D). However, the herbaceous species richness did differ among microsites; more herbaceous species were found on the soil compared to $A$. distichantha plants, whereas the species richness on $B$. serra plants was not different from the other microsites (figure 1E). Therefore, the proportion of woody species on $A$. distichantha and B. serra plants was higher than in the soil samples (figure 1F).

The total richness of woody species was not different among different microsites (figure 2). In contrast, seeds of herbaceous species retrieved from the soil showed a higher total richness than that observed in seeds found on both bromeliads. There were no differences in total richness of herbaceous species between bromeliad species (figure 2).

\section{DISCUSSION}

The results show that both bromeliads (i.e. A. distichantha and B. serra) dwelling in the understory of the xerophytic forest of the Southern Chaco, Argentina, could be considered as microsites where seeds of several woody species accumulate. There were more seeds of woody species on $A$. distichantha than on the soil, whereas $B$. serra 
Table 1. Seed abundance and frequency of woody and herbaceous species found on Aechmea distichantha (Ad) and Bromelia serra (Bs) plants and in the soil samples.

Abundancia y frecuencia de semillas de especies leñosas y herbáceas encontradas sobre plantas de Aechmea distichantha y Bromelia serra y en las muestras de suelo.

\begin{tabular}{|c|c|c|c|c|c|c|c|c|}
\hline \multirow{2}{*}{$\begin{array}{c}\text { Growth } \\
\text { form }\end{array}$} & \multirow{2}{*}{ Species } & \multirow{2}{*}{ Family } & \multicolumn{3}{|c|}{ Abundance } & \multicolumn{3}{|c|}{ Frequency } \\
\hline & & & Ad & Bs & Soil & Ad & Bs & Soil \\
\hline \multirow{10}{*}{$\begin{array}{c}\text { Trees } \\
\text { and } \\
\text { shrubs }\end{array}$} & Schinopsis balansae Engl. & Anacardiaceae & 32 & 18 & 3 & 7 & 6 & 1 \\
\hline & Acanthosyris falcata Griseb. & Santalaceae & 5 & 1 & 1 & 1 & 1 & 1 \\
\hline & Holmbergia tweedii (Moq.) Speg. & Chenopodiaceae & 2 & 2 & - & 2 & 2 & - \\
\hline & Achatocarpus praecox Griseb. & Achatocarpaceae & 5 & - & - & 3 & - & - \\
\hline & Prosopis alba Griseb. & Fabaceae & 2 & - & - & 1 & - & - \\
\hline & Schinus fasciculata (Griseb.) IM Johnst. & Anacardiaceae & 1 & - & - & 1 & - & - \\
\hline & Prosopis affinis Spreng. & Fabaceae & - & 1 & - & - & 1 & - \\
\hline & Celtis pallida Torr. & Celtidaceae & - & 1 & - & - & 1 & - \\
\hline & Acacia praecox Griseb. & Fabaceae & - & - & 1 & - & - & 1 \\
\hline & Maytenus vitis-idaea Griseb. & Celastraceae & - & - & 1 & - & - & 1 \\
\hline \multirow[t]{38}{*}{ Herbs } & Panicum sp. 1 & Poaceae & 10 & 5 & 22 & 2 & 4 & 4 \\
\hline & Sisyrinchium minutiflorum Klatt & Iridaceae & 6 & 4 & 2 & 1 & 2 & 2 \\
\hline & Aechmea distichantha Lem. & Bromeliaceae & 25 & - & - & 4 & - & - \\
\hline & Polygonum sp. & Polygonaceae & 1 & - & - & 1 & - & - \\
\hline & Bromelia serra Griseb. & Bromeliaceae & 1 & - & - & 1 & - & - \\
\hline & Chloris sp. & Poaceae & - & 2 & - & - & 1 & - \\
\hline & Poaceae unknown 1 & Poaceae & - & 1 & - & - & 1 & - \\
\hline & Poaceae unknown 2 & Poaceae & - & 1 & - & - & 1 & - \\
\hline & Poaceae unknown 3 & Poaceae & - & 2 & - & - & 1 & - \\
\hline & Poaceae unknown 4 & Poaceae & - & 1 & - & - & 1 & - \\
\hline & Dicot unknown 1 & (Unrecognized) & - & 1 & - & - & 1 & - \\
\hline & Dicot unknown 2 & (Unrecognized) & - & 94 & - & - & 2 & - \\
\hline & Setaria parviflora (Poir) Kerguélen & Poaceae & - & 2 & 9 & - & 2 & 2 \\
\hline & Portulaca sp. & Portulacaceae & - & 2 & 5 & - & 1 & 4 \\
\hline & Carex trachycystis Griseb. & Cyperaceae & - & 1 & 17 & - & 1 & 6 \\
\hline & Tripogandra glandulosa (Seub.) Rohweder & Commelinaceae & - & 1 & 8 & - & 1 & 2 \\
\hline & Dichondra microcalyx (Hallier f.) Fabris & Convolvulaceae & - & - & 8 & - & - & 2 \\
\hline & Solanum curtipes Bitter & Solanaceae & - & - & 7 & - & - & 4 \\
\hline & Panicum sp. 2 & Poaceae & - & - & 5 & - & - & 1 \\
\hline & Panicum sp. 3 & Poaceae & - & - & 5 & - & - & 1 \\
\hline & Dicot unknown 3 & (Unrecognized) & - & - & 4 & - & - & 2 \\
\hline & Cyperus incomtus Kunth & Cyperaceae & - & - & 4 & - & - & 2 \\
\hline & Cerastium sp. & Caryophyllaceae & - & - & 3 & - & - & 3 \\
\hline & Bromus sp. & Poaceae & - & - & 2 & - & - & 1 \\
\hline & Cyperus odoratus L. & Cyperaceae & - & - & 1 & - & - & 1 \\
\hline & Malvaceae unknown & Malvaceae & - & - & 1 & - & - & 1 \\
\hline & Plantago sp. & Plantaginaceae & - & - & 1 & - & - & 1 \\
\hline & Rumex crispus L. & Polygonaceae & - & - & 1 & - & - & 1 \\
\hline & Tridens brasiliensis Nees ex Steud. & Poaceae & - & - & 1 & - & - & 1 \\
\hline & Solanum sisymbriifolium Lam. & Solanaceae & - & - & 1 & - & - & 1 \\
\hline & Amaranthus sp. & Amaranthaceae & - & - & 1 & - & - & 1 \\
\hline & Passiflora sp. & Passifloraceae & - & - & 1 & - & - & 1 \\
\hline & Gomphrena pulchella Mart. & Amaranthaceae & - & - & 1 & - & - & 1 \\
\hline & Cyperus sp. & Сyperaceae & - & - & 1 & - & - & 1 \\
\hline & Setaria globulifera (Steud.) Griseb. & Poaceae & - & - & 1 & - & - & 1 \\
\hline & Dicot unknown 4 & (Unrecognized) & - & - & 2 & - & - & 2 \\
\hline & Dicot unknown 5 & (Unrecognized) & - & - & 1 & - & - & 1 \\
\hline & Dicot unknown 6 & (Unrecognized) & - & - & 1 & - & - & 1 \\
\hline
\end{tabular}

$\mathrm{N}=10$ for all microsites. -: species absent.

$\mathrm{N}=10$ para todos los micrositios. -: especie ausente. 
Woody species
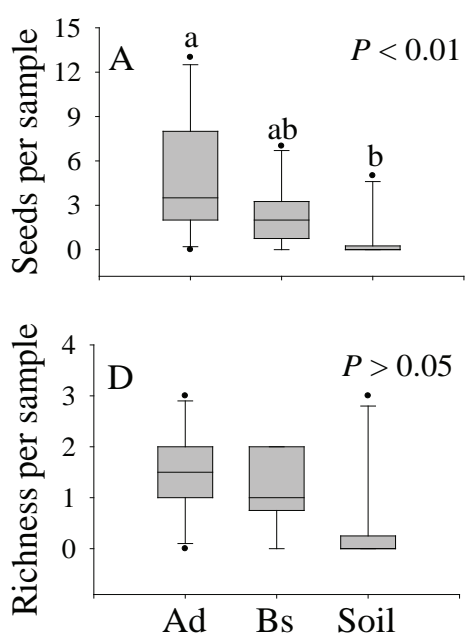

Herbaceous species
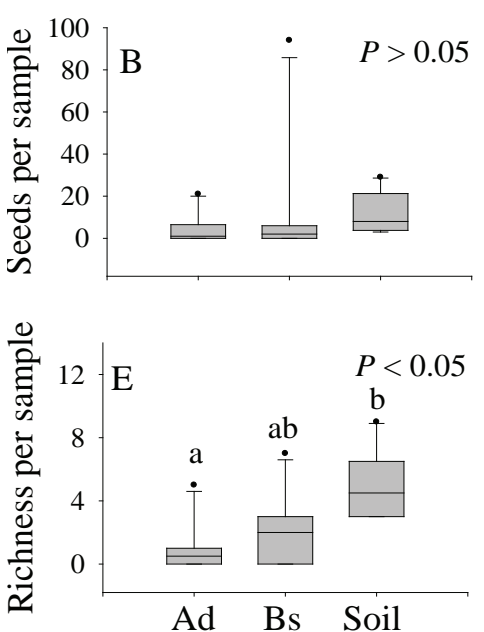

Woody/Total
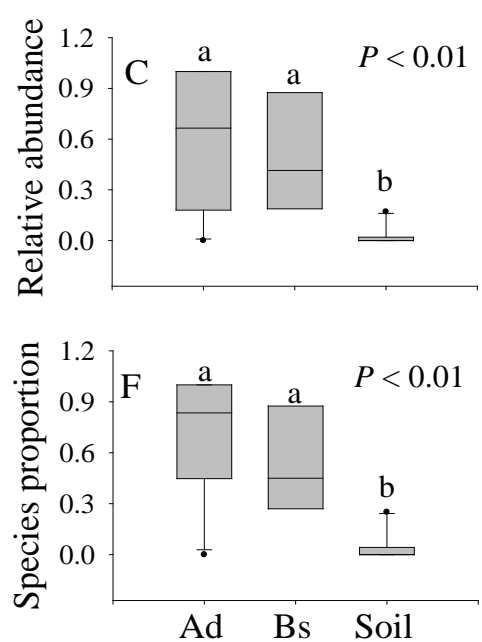

Figure 1. Seed abundance and richness per sample of woody (A, D) and herbaceous (B, E) species captured between the leaves of Aechmea distichantha (Ad) and Bromelia serra (Bs) and found on the soil. Relative woody seed abundance (C) and the proportion of woody species $(\mathrm{F})$ on different seed microhabitats. The lines denote the median, the box boundaries denote the $25^{\text {th }}$ and $75^{\text {th }}$ percentiles, the whiskers denote the $10^{\text {th }}$ and $90^{\text {th }}$ percentil, and the dots denote the outliers $(\mathrm{n}=10)$. Treatments with the same letter do not differed significantly $(P>0.05$; ANOVA test with randomization, MULTIV).

Abundancia (A, B) y riqueza (D, E) de semillas por muestra de especies leñosas (A, D) y herbáceas (B, E) capturadas entre las hojas de Aechmea distichantha (Ad) y Bromelia serra (Bs) y encontradas en el suelo. C) Abundancia relativa y F) proporción de especies leñosas sobre diferentes micrositios. Las líneas muestran la mediana, los límites de las cajas indican los percentiles de 25 y 75, las barras muestran los percentiles de 10 y 90, y los puntos indican los valores extremos. Los tratamientos con letras similares no difieren significativamente $(P>0,05$; ANOVA con aleatorización, MULTIV).

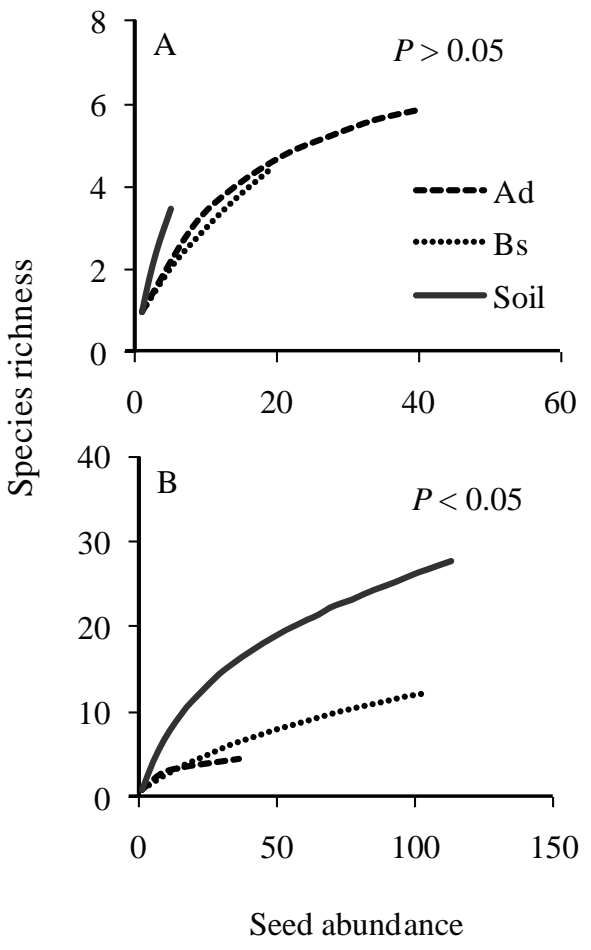

Figure 2. Sample-based rarefaction curves for seeds of woody (A) and herbaceous (B) species captured among the leaves of Aechmea distichantha (Ad) and Bromelia serra (Bs) and found on the soil.

Curvas de rarefacción para semillas de especies leñosas (A) y herbáceas (B) capturadas entre las hojas de Aechmea distichantha (Ad) y Bromelia serra (Bs) y encontradas en el suelo. did not differ with regard to both other microsites. Thus, our first hypothesis was partially supported, whereas our second hypothesis was not supported. Finally, there were marked differences among the patterns recorded for seed accumulation of woody and herbaceous species. Seeds of woody species were more frequent on bromeliads, whereas seeds of herbaceous species were more frequently recorded on the soil, and thus supporting our third hypothesis. These differences in seed accumulation among close microsites may be the result of differences in seed arrival, seed loss, or both.

Differences in seed arrival among microsites may be due to the presence of barriers to seed dispersal (Pounden et al. 2008). For instance, the higher frequency and abundance of Schinopsis balansae seeds on both bromeliad species than on the soil could be related to its anemochorous dispersal syndrome (samaras) (Barberis et al. 2002). Samaras generally have high terminal velocities, thus collisions with small vegetation elements (e.g. bromeliad leaves) are common (Pounden et al. 2008). Likewise, the low seed abundance of herbaceous species is probably related to the height of bromeliads compared to the ground. The latter is based on the fact that herbaceous species richness tended to be lower in A. distichantha (taller) compared to B. serra (shorter). Seed arrival could be also associated with the plant capture area, which is likely to be related to leaf length and foliage arrangement (Cavallero et al. 2009). In the forest under study, B. serra plants have longer diameters than those of 
A. distichantha plants. However, there were no differences between both bromeliads in the abundance or richness of seeds accumulated on their canopy. Thus, future studies should focus on estimating the effects of plant capture areas on seed abundance and richness. Finally, differences in seed arrival among microsites may be associated with directed seed dispersal by animals. For instance, in the restingas of Brazil, it has been shown that frogs choose bromeliad plants (Neoregelia cruenta (Graham) L.B. Smith) as sites where dispersing the seeds of the shrub Erythroxylum ovalifolium Peyr (Fialho 1990). In our forests, even though there are frogs living inside bromeliads (Montero et al. 2010), it is not known whether these animals selectively disperse seeds of woody species onto bromeliads. Tank bromeliads are more likely to attrack animals than nontank bromeliads due to their ability to hold water (Fialho 1990, Benzing 2000), however to our knowledge there is no information about this topic.

Differences in seed loss among close microsites may be due to several alternatively and not mutually exclusive causes. For instance, seeds fallen to the ground could be intensively predated by birds, mammals or insects that inhabit the understory, as has been observed in other forests (Caccia et al. 2006). Alternatively, these seeds may be swept by water runoff after heavy storms, which is likely because the Schinopsis balansae forest has a noticeable micro-relief (Barberis et al. 2002). Seed loss may also be associated with seed germination as has been recorded in the restingas of Brazil, where tank bromeliads facilitate seed germination of some shrub species inside their tanks (Fialho and Furtado 1993, Sampaio et al. 2005). In the forest under study, we have recorded the seed germination of several woody species (e.g. Acacia praecox Griseb., Capparis retusa Griseb., Myrcianthes cisplatensis (Cambess.) O. Berg., Schinopsis balansae, Schinus fasciculata (Griseb.) I.M. Johnst.) inside the tanks of A. distichantha, but not on B. serra (Barberis 1998), therefore seed abundance could have been underestimated on A. distichantha. However, it should be noted that most seedlings recorded inside $A$. distichantha plants did not survive in the following year (Barberis 1998), probably because these species do not have adventitious roots that may grow out of the tank of the bromeliad to continue its development. A similar pattern was observed for the palm Euterpe edulis Mart. seedlings on terrestrial bromeliads in Brazil (Brancalion et al. 2009). These observations suggest that bromeliads actually do not facilitate plant establishment, but reduce woody species regeneration. However, woody species regeneration not only depends on the presence of bromeliads, but also on the amount of seed production. Therefore, further investigations are needed to support these observations.

Finally, it should be noted that seed sampling was carried out just once in this study, thus we only get a picture of the seed accumulation process. As sampling was carried out before the begining of the dispersal period of woody species, seeds of some species may have been inside bromeliads for more than four months depending on their time of seed dispersal, as well as on their seed longevity. On the other hand, as plants of both bromeliad species lived more than one year ${ }^{1}$ some seeds may be even older than that. Thus, longer studies and/or studies that analyze time of seed arrival are required in order to elucidate the importance of bromeliads on seed accumulation.

In conclusion, the canopy of terrestrial bromeliads are favourable microsites for seed accumulation of woody species when compared to the ground outside. This pattern of seed accumulation is the result of differences in seed arrival and loss among microsites. However it is not known whether bromeliads are safe sites for seedling establishment (Schupp 1995). Therefore, before recommending removal of bromeliad colonies, further research is needed in order to elucidate the role of terrestrial bromeliads on the recruitment and regeneration of woody species in the Schinopsis balansae forest.

\section{ACKNOWLEDGEMENTS}

We thank R Commuzzi, L Schaumburg, and S Acosta for their help in Las Gamas, and G Klekailo and three anonymous reviewers for their comments on the manuscript. Funding was provided by FONCYT (BID-1201/ OC-AR-PICT 01-12686) and The Rufford Maurice Laing Foundation. IMB acknowledges a postdoctoral fellowship from CONICET.

\section{REFERENCES}

Álvarez-Sánchez J, S Guevara. 1999. Litter interception on Astrocaryum mexicanum Liebm. (Palmae) in a tropical rain forest. Biotropica 31: 89-92.

Barberis IM. 1998. Distribución y regeneración de especies leñosas en relación con la heterogeneidad ambiental en un bosque de Schinopsis balansae del sur del Chaco oriental. M. Sc. Thesis. Buenos Aires, Argentina. Facultad de Agronomía, Universidad de Buenos Aires. 128 p.

Barberis IM, JP Lewis. 2005. Heterogeneity of terrestrial bromeliad colonies and regeneration of Acacia praecox (Fabaceae) in a humid-subtropical-Chaco forest, Argentina. Revista de Biología Tropical 53: 377-385.

Barberis IM, WB Batista, EF Pire, JP Lewis, RJC León. 2002. Woody population distribution and environmental heterogeneity in a Chaco forest, Argentina. Journal of Vegetation Science 13: 607-614.

Benzing DH. 2000. Bromeliaceae. Profile of an Adaptive Radiation. Cambridge, UK. Cambridge University Press. $708 \mathrm{p}$.

Brancalion PHS, VA Gabriel, JM Gómez. 2009. Do terrestial tank bromeliads in Brazil create safe sites for palm establishment or act as natual traps for its dispersed seeds? Biotropica 41: 3-6.

Brokaw NVL. 1983. Groundlayer dominance and apparent inhibition of tree regeneration by Aechmea magdalenae

\footnotetext{
1 Barberis IM: personal observations.
} 
(Bromeliaceae) in a tropical forest. Tropical Ecology 24: 194-200.

Brooker RW, FT Maestre, RM Callaway, CL Lortie, LA Cavieres, G Kunstler, $\mathrm{P}$ Liancourt, $\mathrm{K}$ Tielbörger, JMJ Travis, F Anthelme, C Armas, L Coll, E Corcket, S Delzon, E Forey, Z Kikvidze, J Olofsson, F Pugnaire, CL Quiroz, P Saccone, K Schiffers, M Seifan, B Touzard, R Michalet. 2008. Facilitation in plant communities: the past, the present, and the future. Journal of Ecology 96: 18-34.

Caccia FD, EJ Chaneton, T Kitzberger. 2006. Trophic and nontrophic pathways mediate apparent competition through post-dispersal seed predation in a Patagonian mixed forest. Oikos 113: 469-480.

Caccia F, E Chaneton, T Kitzberger. 2009. Direct and indirect effects of understorey bamboo shape tree regeneration niches in a mixed temperate forest. Oecologia 161: 771780 .

Cavallero L, D López, IM Barberis. 2009. Morphological variation of Aechmea distichantha (Bromeliaceae) in a Chaco forest: habitat and size-related effects. Plant Biology 11: 379-391.

Espino LM, MA Seveso, MA Sabatier. 1983. Mapa de suelos de la provincia de Santa Fe. Tomo II. Santa Fe, Argentina. MAG Santa Fe e INTA EERA Rafaela. 220 p.

Fialho RF. 1990. Seed dispersal by a lizard and a treefrog. Effect of dispersal site on seed survivorship. Biotropica 22: 423424.

Fialho RF, ALS Furtado. 1993. Germination of Erythroxylum ovalifolium (Erythroxylaceae) seeds within the terrestrial bromeliad Neoregelia cruenta. Biotropica 25: 359-362.

George LO, FA Bazzaz. 1999. The fern understory as an ecological filter: emergence and establishment of canopytree seedlings. Ecology 80: 833-845.

Gotelli NJ, GL Entsminger. 2002. EcoSim: Null Models Software for Ecology, version 7. Burlington, USA. Acquired Intelligence Inc. and Kesey-Bear. Accessed $3^{\text {rd }}$ Sept. 2003. Available in http://www.garyentsminger.com/ecosim/ index.htm

Lewis JP, EF Pire, IM Barberis. 1997. Structure, physiognomy and species composition of a Schinopsis balansae (Anacardiaceae) forest in the Southern Chaco, Argentina. Revista de Biología Tropical 45: 1013-1020c.
Martínez Crovetto R. 1980. Estudios fitosociológicos en el sotobosque de los quebrachales del noroeste de Corrientes (República Argentina). Boletín de la Sociedad Argentina de Botánica 19: 315-329.

Montero G, C Feruglio, IM Barberis. 2010. The phytotelmata and foliage macrofauna assemblages of a bromeliad species in different habitats and seasons. Journal of Insect Conservation and Diversity 3: 92-102

Pensiero JF, HF Gutiérrez, AM Luchetti, E Exner, V Kern, E Brnich, LJ Oakley, DE Prado, JP Lewis. 2006. Flora vascular de la provincia de Santa Fe. Santa Fe, Argentina. Universidad Nacional del Litoral. 403 p.

Pillar VD. 2004. MULTIV. Multivariate Exploratory Analysis, Randomization Testing and Bootstrap Resampling User's Guide v. 2.3.10. Porto Alegre, Brasil. Universidade Federal do Rio Grande do Sul. Accessed $28^{\text {th }}$ Sept. 2006. Available in http://ecoqua.ecologia.ufrgs.br/ecoqua/MULTIV.html

Pounden E, DF Greene, M Quesada, JM Contreras Sánchez. 2008. The effect of collisions with vegetation elements on the dispersal of winged and plumed seeds. Journal of Ecology 96: 591-598.

Royo AA, WP Carson. 2006. On the formation of dense understorey layers in forests worldwide: consequences and implications for forest dynamics, biodiversity, and succession. Canadian Journal of Forest Research 36: 13451362.

Sampaio MC, FX Picó, FR Scarano. 2005. Ramet demography of a nurse bromeliad in Brazilian restingas. American Journal of Botany 92: 674-681.

Schupp EW. 1995. Seed-seedling conflicts, habitat choice, and patterns of plant recruitment. American Journal of Botany 82: 399-409.

Smith LB, RJ Downs. 1979. Bromeliaceae, subfamily Bromelioideae. Flora Neotropica 14(2): 1493-2142.

Tuesca D, L Nisensohn, SI Boccanelli, PS Torres, JP Lewis. 2004. Weed seedbank and vegetation dynamics in summer crops under two contrasting tillage regimes. Community Ecology 5: 247-255.

Wenzel M, H Hampel. 1998. Regeneración de las principales especies arbóreas del Chaco húmedo argentino. Quebracho 6: 5-18. 